\title{
The effect of superovulation on the contributions of individual blastomeres from 2-cell stage CF1 mouse embryos to the blastocyst
}

\author{
MIKA KATAYAMA ${ }^{1}$ and R. MICHAEL ROBERTS*,1,2 \\ ${ }^{1}$ Division of Animal Sciences and ${ }^{2}$ Department of Biochemistry, Christopher S. Bond Life Sciences Center, \\ University of Missouri, Columbia, MO, USA
}

\begin{abstract}
It remains controversial whether blastomeres of 2-cell stage mouse embryos show bias in their contribution to the blastocyst and whether there is any effect of superovulation. Twocell stage embryos from CF1 mice were derived by either natural breeding (N) or superovulation (S) and cultured in vitro. At blastocyst, inner cell mass and trophectoderm were distinguished by Cdx2 and Oct4 immunostaining. A fluorescent dye (CM-Dil) was also used to tag individual blastomeres at the 2-cell stage, and the descendant cells identified by their red fluorescence. $S$ and $\mathrm{N}$ embryos developed to blastocyst at the same rate and contained a similar number of cells. However, with S embryos, the descendants of the blastomere labeled with CM-Dil contributed predominantly to either the embryonic or abembryonic pole about $70 \%$ of the time, whereas most $\mathrm{N}$ embryos displayed random patterning, with no restriction to one or other of the poles. In Sembryos, but not $\mathrm{N}$-embryos, the leading blastomere at second cleavage contributed preferentially to the embryonic pole of the blastocyst and the lagging blastomere to the abembryonic pole and hence mural trophectoderm. In addition, a tetrahedral rather than a "flat" morphology at the 4-cell stage of S-embryos was strongly biased to displaying the embryonic/abembryonic pattern at blastocyst. In contrast, $\mathrm{S}$-embryos lacking a zona pellucida resembled $\mathbf{N}$ embryos in their patterning. In CF1 mice, superovulation has little effect on development to blastocyst, but enforces a greater degree of lineage restriction than natural breeding, most likely through constraints imposed by the zona pellucida.
\end{abstract}

KEY WORDS: Cdx2, Oct4, inner cell mass, trophectoderm, CM-DiI

\section{Introduction}

The first discernible cell lineage decision during murine embryo development is the establishment of the precursor cell populations of the inner cell mass (ICM) and trophectoderm (TE). While the ICM is the source of cells that give rise to the embryo proper, TE is the progenitor of the trophoblast component of the fetal placenta. It is now recognized that in the mouse the position of a blastomere within the morula at about the 16-cell stage biases its fate. Those on the outside contribute predominantly to TE, while those with an interior location are generally fated to become the pluripotent ICM lineage (Johnson et al. 2004). An initial event in the emergence of TE is cell polarization, a process that begins at about the 8-cell stage, approximately $48 \mathrm{~h}$ after fertilization and maximizes contact between blastomeres and promotes cell to cell adherence and junctional complex formation (Johnson et al. 2004). These polarized blastomeres can divide either along their axis of polarity, i.e. roughly perpendicular to their outer surfaces, to create two outer cells or more or less orthogonally to the axis of polarity to form a population of inner cells constituted primarily from the basolateral cytoplasm. As a result, the 16-cell stage morula usually consists of 8 to 11 outer cells and 5 to 8 inner cells

\footnotetext{
Abbreviations used in this paper: CM-DiI, chloromethylbenzamido-1,1 2dioctadecyl-3,3-3 2,3 2tetramethylindocarbocyanine; h pc, hours post coitus; ICM, inner cell mass; N, natural breeding; S, superovulation; TE, trophectoderm; ZP, zona pellucida.
}

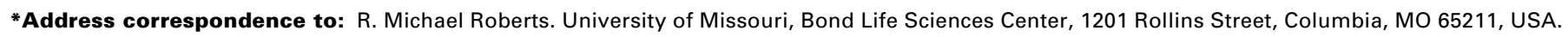
e-mail: robertsrm@missouri.edu

Supplementary Material for this paper (one figure and 7 movies) is available at: http://dx.doi.org/10.1387/ijdb.092942mk 
(Suwinska et al. 2008), although more extreme ranges are occasionally encountered.

It remains unclear exactly how the axis along which the individual blastomeres of 8-cell stage embryos divide is determined. On the one hand, it has been argued that blastomeres at this stage are essentially equivalent, but that those with a greater exposed surface are the ones most likely to form two polarized outer cells, while those with less outer surface and a bulkier interior probably produce one polar and one inner cell (Johnson et al. 2004). In this model, the informational cues that direct cell cleavage are simply positional. An alternative hypothesis is that, by the 8-cell stage, embryos are biochemically asymmetrical as a result of apportionment of different regions of a pre-patterned zygote cytoplasm (Gardner, 2001; Zernicka-Goetz, 2006). Even if pre-patterning exists, however, programming is clearly not inflexible, since, at the morula stage, inside, apolar cells can become polarized if placed in an outside position and outside cells placed internally can contribute to the inner cell mass (Johnson et al. 2004).

Evidence for pre-patterning in mouse embryo development has emerged over the past decade, with several studies concluding that a degree of developmental asymmetry exists as early as the 2-cell stage as the result of the specific orientation of the first cleavage plane of the zygote occurring close to the animalvegetal axis in the vicinity of the second polar body (ZernickaGoetz, 2006). It has been noted, for example, that the progeny of the earliest dividing blastomere of 2-cell stage embryos, tend to make a greater contribution to the embryonic pole of the eventual blastocyst than does the lagging blastomere, an allocation that depends on the specific orientation of the two second cleavage divisions. On the other hand, others believe that the first cleavage division is somewhat random in its orientation and that there is an inherent symmetry to early mouse development (Hiiragi et al. 2004; Kurotaki et al. 2007; Motosugi et al. 2005). Moreover, it is argued that there is no bias to the fates of the blastomeres at the 2-cell stage as determined by lineage tracing experiments (Alarcon et al. 2003; Chroscicka et al. 2004; Motosugi et al. 2005; Waksmundzka et al. 2006). Instead, blastocyst formation is inferred to be driven entirely by positional cues, due, at least in part, to the confining effects of the surrounding zona pellucida (ZP) (Dietrich et al. 2007; Honda et al. 2008; Kurotaki et al. 2007).

Here we have re-addressed the issue of asymmetries in the murine embryo as it makes the transition from zygote to blastocyst and show that for the CF1 mouse strain superovulation imposes a greater degree of lineage restriction than natural breeding, although this limitation on blastomere cell fate is lifted if the ZP"is removed at the 2-cell stage of development.

\section{Results}

\section{Expression of Oct4 and Cdx2 during early development of murine embryos}

Cdx2 expression is regarded as a marker of TE and TE precursors (Strumpf et al. 2005) and is absent from ICM and pluripotent murine cells, although there have been mixed reports as to how early $\mathrm{Cdx} 2$ is expressed in murine development (Niwa et al. 2005; Ralston et al. 2008; Strumpf et al. 2005). Oct4, on the other hand, although often regarded as a relatively specific marker of pluripotent cells, is also expressed in TE of murine blastocysts (Dietrich et al. 2007). Hence, in blastocysts at 84 and $108 \mathrm{~h} \mathrm{pc}$ Oct4+/Cdx2- cells represent ICM and Oct4+/Cdx2+ cells TE, while, in morulae, cells strongly positive for $\mathrm{Cdx} 2+$ are likely to be TE precursors (Jedrusik et al. 2008). Here CF1 embryos (derived after both superovulation and natural breeding) were fixed at increasing times post coitus and stained for the two transcription factors to confirm that $\mathrm{Cdx} 2$ can be used as a specific marker for trophectoderm in blastocysts. As an additional control, we also examined naturally bred embryos from NIH-Swiss mice.

As expected, Oct4, was expressed in nuclei of all cells from the 2-cell until the expanded blastocyst stage (data not shown). Similarly, all morula stage embryos ( $84 \mathrm{~h} \mathrm{pc}$ ) from both mouse strains demonstrated some cells positive for Cdx2 (data not shown), In general, outer blastomeres were positive, but weaker staining was associated with some inner ones as well. In blastocysts (108 h pc), Cdx2 was localized exclusively to the nuclei of TE and was absent from cells of the ICM, which stained only for Oct4 (Fig. 1A). In the few hatching blastocysts observed, the expression of Oct4 had declined markedly in TE, but was still detectable in all nuclei Fig. 1B). Together, these results indicated no marked deviation from the expected patterns of Oct4 and Cdx2 expression in the outbred CF1 and NIH Swiss relative to other strains. The data confirmed that all $\mathrm{Cdx} 2$-staining cells in blastocysts were trophectoderm, while the ICM was positive only for Oct4.

\section{Relative numbers of TE and ICM cells in natural breeding and superovulation embryos at $108 \mathrm{~h}$ pc}

Total cell numbers and numbers of Oct4/Cdx2- (ICM) cells and

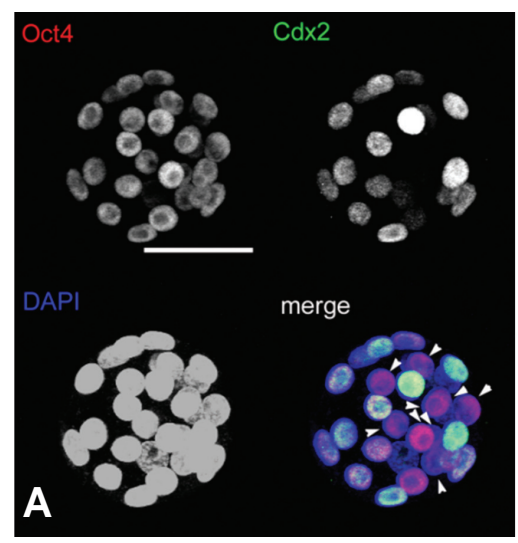

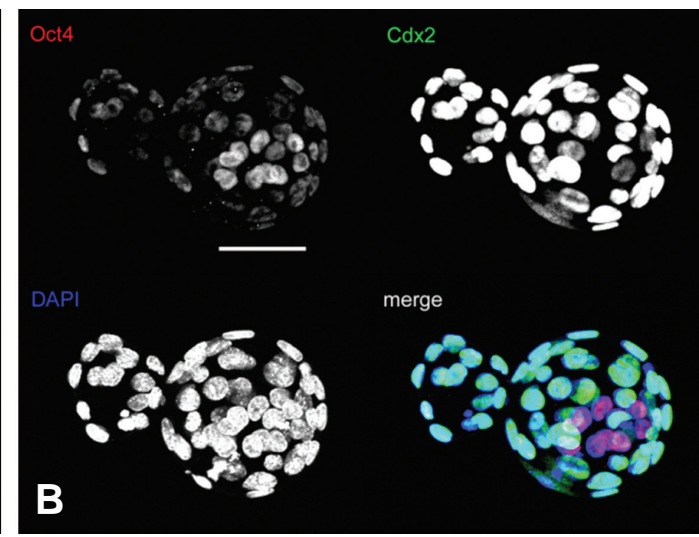

Fig. 1. Relative localization of Oct4 and Cdx2 in CF1 murine blastocysts. These are images of embryos (108 $h$ pc) from CF-1 superovulated dams created by projection of series of confocal sections (4-6 $\mu$ m each) for Oct4 (upper left), Cdx2 (upper right) and DAPI (lower left). (A) early blastocyst; (B) hatching blastocyst. Arrowheads in (A) indicate Oct4+/Cdx2-cells, namely ICM, in an early blastocyst in which Oct4 is expressed relatively uniformly in both ICM and TE. By contrast, in a more advanced, hatching blastocyst (B), Oct4 is expressed much more strongly in ICM than in TE. Scale bars represent $50 \mu \mathrm{m}$. 
TABLE 1

NUMBERS OF OCT4+/CDX2- (ICM) AND OCT4+/CDX2+ (TE) IN CONTROL BLASTOCYSTS DERIVED FROM NATURAL BREEDING (N) AND SUPEROVULATION (S) AT 108 H PC

\begin{tabular}{ccccccc}
\multirow{2}{*}{$\begin{array}{c}\text { Mouse } \\
\text { strain }\end{array}$} & \multirow{2}{*}{$\begin{array}{c}\text { Type of } \\
\text { ovulation }\end{array}$} & \multirow{2}{*}{$\begin{array}{c}\text { Embryo } \\
\text { number }\end{array}$} & \multicolumn{3}{c}{ Number of cells } & \begin{tabular}{c} 
Fraction \\
\cline { 4 - 6 }
\end{tabular} \\
\cline { 4 - 7 } & $\mathrm{S}$ & 15 & $69.4 \pm 9.9^{\mathrm{a}}$ & $18.0 \pm 3.9^{\mathrm{a}}$ & $49.7 \pm 7.4^{\mathrm{a}}$ & $0.27^{\mathrm{a}}$ \\
\hline $\mathrm{CF}-1$ & $\mathrm{~S}$ & 18 & $61.9 \pm 19.3^{\mathrm{a}}$ & $17.8 \pm 6.7^{\mathrm{a}}$ & $41.4 \pm 15.0^{\mathrm{a}}$ & $0.30^{\mathrm{a}}$ \\
$\mathrm{CF}-1$ & $\mathrm{~N}$ & 20 & $53.8 \pm 13.5^{\mathrm{a}}$ & $17.2 \pm 3.9^{\mathrm{a}}$ & $35.6 \pm 12.8^{\mathrm{a}}$ & $0.34^{\mathrm{a}}$ \\
\hline
\end{tabular}

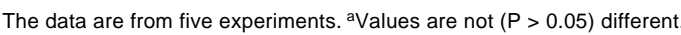

\section{TABLE 2}

EMBRYO DEVELOPMENT AT 108 H PC AFTER DII-CM CELL TRACING FOLLOWING NATURAL BREEDING (N) AND SUPEROVULATION (S)

\begin{tabular}{ccccc}
$\begin{array}{c}\text { Mouse } \\
\text { strain }\end{array}$ & $\begin{array}{c}\text { Type of } \\
\text { ovulation }\end{array}$ & Treatment & Total & Number of blastocysts (\%) \\
\hline CF-1 & S & Dil-CM & 57 & $50(88 \pm 9)^{\mathrm{a}}$ \\
& & Control & 50 & $43(86 \pm 6)^{\mathrm{a}}$ \\
CF-1 & $\mathrm{N}$ & Dil-CM & 57 & $52(91 \pm 6)^{\mathrm{a}}$ \\
& & Control & 36 & $33(92 \pm 8)^{\mathrm{a}}$ \\
NIH-Swiss & $\mathrm{N}$ & Dil-CM & 65 & $58(89 \pm 4)^{\mathrm{a}}$ \\
& & Control & 45 & $42(93 \pm 6)^{\mathrm{a}}$ \\
\hline
\end{tabular}

The data are from five experiments. ${ }^{a}$ Values are not $(P>0.05)$ different. Numbers in parentheses are percentages \pm S.D.

of Oct4/Cdx2+ (TE) cells in $\mathrm{S}$ and $\mathrm{N}$ blastocysts were similar at $108 \mathrm{~h}$ pc (Table 1). There was no effect of mouse strain (CF1 versus NIH Swiss). In addition, about $90 \%$ of 2 -cell stage embryos recovered from S and N CF1 dams had progressed to blastocyst by $108 \mathrm{~h} \mathrm{pc}$ (see Table 2). In conclusion, there appeared to be no overt effects of superovulation on the development of embryos from CF1 dams.

\section{Cell fates of 2-cell blastomeres traced by CM-Dil}

Here the goal was to confirm whether or not blastomeres at the 2-cell stage from $\mathrm{N}$ and $\mathrm{S}$ dams are predisposed to different fates, and, in particular, whether the progeny of one blastomere is biased to form mural trophectoderm and the other to contribute mainly to ICM and polar trophectoderm. To accomplish this goal, one of the two blastomeres was tagged by depositing a small volume of CM-Dil, a fluorescent dye that survives standard fixation procedures, on its surface. Embryos were then allowed to progress in development for various times, fixed, and then stained for Cdx2 at blastocyst to distinguish ICM and TE cells (see Supplementary Fig. 1 A-G and associated movies which can be viewed online at http://dx.doi.org/10.1387/ijdb.092942mk).

CM-Dil labeling did not compromise embryo development. Tagged 2-cell stage embryos (Fig. 2A) progressed to blastocyst between $84 \mathrm{~h}$ and $108 \mathrm{~h}$ as rapidly as control embryos (Table 2), and sufficient fluorescent dye persisted to allow the progeny of the tagged blastomere to be followed through the subsequent four rounds of cell cleavage Fig. $2 \mathrm{~B}-\mathrm{F}$ ). In all embryos at $64 \mathrm{~h} \mathrm{pc}$, when the majority were at the 8-cell stage, labeled cells formed a clonal group occupying one end of the embryo (Fig. 2C). This lack of intermingling of the labeled and unlabeled cells persisted to the 84 h, 16-cell morula stage (Fig. 2D) in all embryo types (data not shown).

In $\mathrm{N}$ blastocysts, only about one-third of the CM-Dil-tagged blastocysts had label confined primarily to either their embryonic or abembryonic poles. The remaining two-thirds showed a more random distribution of labeled cell progeny, with no biased distribution to either one pole or the other (Table 3). These values are similar to ones reported by others employing a comparable blastomere-marking approach (Alarcon et al. 2005). However, blastocysts derived from superovulated CF-1 oocytes provided a contrasting picture, with $74 \%$ demonstrating a relatively polarized distribution of tagged cells (32\% embryonic; $43 \%$ abembryonic) and only $25 \%$ an intermingled pattern. As noted by others (Zernicka-Goetz, 2006), even when the allocation of cells from the CM-Dil-tagged blastomere was judged to be associated predominantly with the abembryonic pole, the clonal boundary was not absolute and one or more labeled cells usually contributed to part of the ICM and vice versa (data not shown).

\section{Effect of order and plane of cell cleavage of 2-cell stage embryos on CM-Dil labeling patterns in blastocysts}

These experiments employed CF-1 embryos from superovu-
Fig. 2. Cell fates of blastomeres tagged at the 2-cell stage of development with Dil-CM. After tagging one randomly chosen blastomere with the membrane dye, Dil-CM (red) at the 2-cell stage of development, embryos were allowed to proceed in their development through various intermediary stages until they reached blastocyst. Each embryo was counter stained with DAPI (blue) and anti-Cdx2 antibody (green). (A) 2cell stage embryos; (B) 4-cell stage; (C) 8-cell stage; (D) morula. In blastocysts, labeled cell progeny were frequently concentrated towards either the abembryonic pole [ (E) red cells located opposite the ICM] or the embryonic pole [ (F) red cells associated with the region occupied by the ICM and polar trophectoderm]. Supplementary Fig. S1 A-F provides the original confocal stacks for Fig. 2 A-F, and also for a blastocyst with a typically random distribution of Dil (Supplementary Fig. S1G) in which there was no preferential localization to either the embryonic or abembryonic poles.
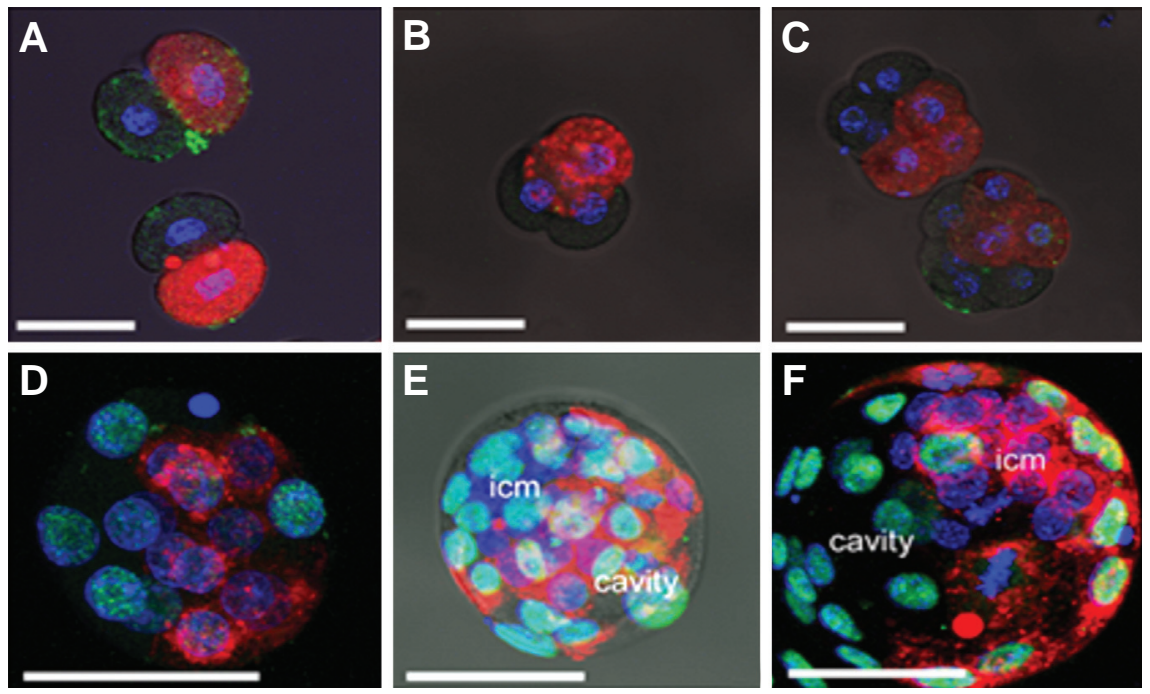
lated females. One of two blastomeres at the 2-cell stage was tagged with dye and placed in culture. Embryos were selected at the 3-cell stage $(n=98)$ between 48 and $52 \mathrm{~h} \mathrm{pc}$ and sorted into those in which the tagged blastomere either cleaved first $(n=49$, leading) or last ( $n=49$, lagging). Embryos, now in two groups, were then cultured to $108 \mathrm{~h} \mathrm{pc}$ when they were fixed. A total of 40 leading and 38 lagging embryos had reached the blastocyst stage by this time and were examined for the distribution of label. When the leading blastomere had been tagged, its progeny contributed preferentially to the embryonic pole of the blastocyst about half the time $(21 / 40 ; 53 \%)$. About one third of these blastocysts (13/ 40) demonstrated an intermingled distribution of labeled cells with no specific localization to either the embryonic and abembryonic poles, while a smaller fraction (6/40) were labeled predominantly at their abembryonic end. When the cell progeny of the lagging blastomere were examined, $50 \%$ occupied the abembryonic end (19/38), $16 \%(6 / 38)$ had a random pattern, while $34 \%(13 / 38)$ occupied the embryonic pole. This experiment confirmed that the leading blastomere at second cleavage contributed preferentially to the embryonic pole and the lagging blastomere to the abembryonic pole, and hence mural TE, when superovulated dams were employed as a source of oocytes.

Three possible arrangements of cells have been noted at the 4-cell stage depending upon the sequence of cleavage planes at the second cell division (Piotrowska-Nitsche etal.2005; ZernickaGoetz, 2006). The most common, a tetrahedral form, has been suggested to result from one blastomere dividing along an approximate meridional $(\mathrm{M})$ plane and the other on an approximately equatorial $(E)$ plane. The other two forms, which are outcomes of either two M divisions or two $\mathrm{E}$ divisions, respectively, place the four blastomeres in approximately the same plane. Here $\mathrm{N}$ and $\mathrm{S}$ embryos were tagged with dye at the 2-cell stage and collected into two groups, i.e. tetrahedral or planar (flat), when they reached the 4-cell stage $56 \mathrm{~h} \mathrm{pc}$. They were then cultured to $108 \mathrm{~h} \mathrm{pc}$ to determine how the orientation of second cleavage affected cell distribution at blastocyst (Table 4).

The type of ovulation did not affect the incidence of tetrahedral and flat 4-cell embryos. Of $44 \mathrm{~N}$ embryos $59 \%$ (27/44) were tetrahedral and $41 \%$ relatively planar (17/44). With S embryos, 62 $\%$ were tetrahedral (32/52) and $38 \%(20 / 52)$ planar. Overall, N embryos again tended to show a random distribution of labeled cell progeny between the embryonic and abembryonic poles (Table 4), although this mixed allocation was observed more frequently $(\mathrm{P}<0.05)$ in blastocysts derived from the more planar conformations than from tetrahedral 4-cell embryos. Tetrahedral
TABLE 3

\section{CELL FATE AT BLASTOCYST OF INDIVIDUAL BLASTOMERES LABELED WITH DII-CM AT THE 2-CELL STAGE}

\begin{tabular}{cccccc}
\multirow{2}{*}{$\begin{array}{c}\text { Mouse } \\
\text { strain }\end{array}$} & $\begin{array}{c}\text { Type of } \\
\text { ovulation }\end{array}$ & \multicolumn{4}{c}{ Number of blastocysts and localization of Dil-CM positive cells } \\
\cline { 3 - 6 } & $\mathrm{S}$ & 38 & $10(25 \pm 6)^{\mathrm{a}}$ & $12(32 \pm 4)^{\mathrm{a}}$ & $16(43 \pm 6)^{\mathrm{a}}$ \\
\hline CF-1 & $\mathrm{N}$ & 52 & $36(68 \pm 5)^{\mathrm{b}}$ & $8(15 \pm 3)^{\mathrm{b}}$ & $8(17 \pm 4)^{\mathrm{b}}$ \\
CF-1 & $\mathrm{N}$ & 34 & $22(66 \pm 10)^{\mathrm{b}}$ & $7(20 \pm 4)^{\mathrm{b}}$ & $5(14 \pm 13)^{\mathrm{b}}$ \\
\hline NIH-Swiss & $\mathrm{N}$ & 34 &
\end{tabular}

The data are from seven experiments. Numbers in parentheses are percentages \pm S.D. a,b Values within columns with different superscripts are significantly $(P<0.05)$ different.

\section{TABLE 4}

CELL FATE AT BLASTOCYST OF INDIVIDUAL BLASTOMERES LABELED WITH DII-CM AT THE 2-CELL STAGE ACCORDING TO BLASTOMERE ORIENTATION AT THE 4-CELL STAGE

\begin{tabular}{cccccc}
\multirow{2}{*}{$\begin{array}{c}\text { Type of } \\
\text { ovulation }\end{array}$} & Orientation & \multicolumn{4}{c}{ Number of blastocysts and localization of Dil-CM positive cells } \\
\cline { 2 - 6 } & Ootal & Random & Embryonic & Abembryonic \\
\hline $\mathrm{S}$ & $\mathrm{T}$ & 32 & $9(28 \pm 2)^{\mathrm{a}}$ & $10(31 \pm 4)^{\mathrm{a}}$ & $13(41 \pm 3)^{\mathrm{a}}$ \\
& $\mathrm{P}$ & 20 & $13(73 \pm 21)^{\mathrm{b}}$ & $4(17 \pm 12)^{\mathrm{a}}$ & $3(11 \pm 13)^{\mathrm{b}}$ \\
\hline $\mathrm{N}$ & $\mathrm{T}$ & 27 & $17(63 \pm 4)^{\mathrm{A}}$ & $5(18 \pm 12)^{\mathrm{A}}$ & $5(19 \pm 14)^{\mathrm{A}}$ \\
& $\mathrm{P}$ & 17 & $16(94 \pm 10)^{\mathrm{B}}$ & $0(0 \pm 0)^{\mathrm{B}}$ & $1(5 \pm 10)^{\mathrm{A}}$ \\
\hline
\end{tabular}

Data are from six experiments. Values in parentheses are percentages \pm S.D. When superscripts $\mathrm{a}, \mathrm{b}$ and $\mathrm{A}, \mathrm{B}$ differ within columns, values are significantly different $(\mathrm{P}<0.05)$. ${ }^{*}$ tetrahedral, $\mathrm{T}$; planar, P.

N embryos provided $63 \%$ blastocysts with a mixed patterning and $37 \%$ with labeled cells confined predominantly to either the embryonic (18\%) or abembryonic (19\%) poles.

In the case of $\mathrm{S}$ embryos, over $70 \%$ of the tetrahedral 4 -cell embryos partitioned labeled cells to either the embryonic or abembryonic poles of the blastocyst, with the remainder providing the mixed pattern. As observed with the $\mathrm{N}$-embryos, flat conformations at the 4-cell stage gave rise largely to blastocysts with a mixed patterning.

\section{Effects of ZP removal on CM-Dil labeling cells in blastocysts}

In this experiment, embryos were collected only from superovulated CF-1 dams. After tagging one blastomere with CM-Dil at the 2-cell stage, the ZP was removed from some embryos, while in others it was left intact. Embryos were cultured individually to $108 \mathrm{~h} \mathrm{pc}$ and then examined for the distribution of the fluorescent dye (Table 5). There was no effect of ZP removal on progression to blastocyst. By contrast, ZP removal significantly increased the

TABLE 5

EFFECT OF REMOVAL OF THE ZONA PELLUCIDA ON CELL FATE AT BLASTOCYST OF INDIVIDUAL BLASTOMERES LABELED WITH DII-CM AT THE 2-CELL STAGE

\begin{tabular}{|c|c|c|c|c|c|c|c|}
\hline \multirow[b]{2}{*}{ Type of ovulation } & \multirow[b]{2}{*}{ Treatment $^{*}$} & \multicolumn{2}{|c|}{ Embryo development } & \multicolumn{4}{|c|}{ Localization of Dil-CM positive cells } \\
\hline & & Total embryos & Number of blastocysts & Total & Random & Embryonic & Abembryonic \\
\hline $\mathrm{S}$ & Control & 8 & $8(100 \pm 0)^{\mathrm{a}}$ & & & & \\
\hline S & ZP- & 11 & $10(92 \pm 17)^{\mathrm{a}}$ & & & & \\
\hline$S$ & Dil & 16 & $13(81 \pm 13)^{b}$ & 13 & $3(21 \pm 14)^{\mathrm{a}}$ & $5(40 \pm 13)^{a}$ & $5(40 \pm 13)^{a}$ \\
\hline $\mathrm{s}$ & $\mathrm{Dil} / \mathrm{ZP}-$ & 32 & $27(84 \pm 6)^{b}$ & 26 & $18(70 \pm 8)^{\mathrm{b}}$ & $5(19 \pm 5)^{\mathrm{b}}$ & $3(11 \pm 7)^{b}$ \\
\hline
\end{tabular}

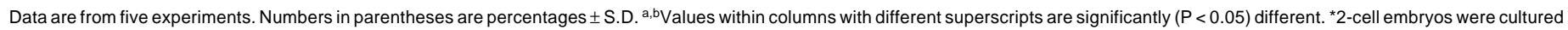

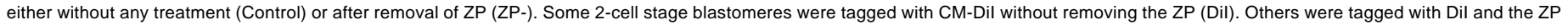
removed (Dil/ZP-). 
fraction of blastocysts in which labeled cells were randomly distributed between the embryonic and abembryonic poles.

\section{Discussion}

The establishment of the abembryonic-embryonic axis (based on the orientation of blastocoel cavity) and the trophoblast lineage are fundamental features of early mammalian development, yet the directive processes that determine these outcomes still remain controversial. Some investigators argue that early cleavage divisions generate cells with identical potential in terms of generating ICM and TE and are not in any way predictive of cell fate (Alarcon et al. 2003; Chroscicka et al. 2004; Hiiragi et al. 2004; Kurotaki et al. 2007; Motosugi et al. 2005). A contrasting view is that there are already some differences established between the blastomeres of the 2-cell stage embryo, most probably as a result of differential partitioning of oocyte contents when the zygote undergoes cleavage (Gardner, 2001), and that these differences play a part in guiding but not necessarily imposing cell fate decisions, including information that influences the orientation and order of subsequent cell divisions (Zernicka-Goetz, 2006).

Perhaps nothing in this field has generated more disagreement and has been more difficult to reconcile than the various forms of lineage tracing experiments. When we used naturally bred mice, a blastomere tagged at the 2-cell stage contributed predominantly to either the abembryonic or embryonic pole approximately onethird of the time in both CF1 and $\mathrm{NIH}$ Swiss strains. In the remaining cases, labeled cells contributed randomly to both poles to provide a mixed cell allocation, a result more in line with those who reject pre-patterning than those who favor it. With embryos from superovulated CF1 dams, the situation was reversed. Labeled cells occupied most of one or other of the two poles approximately $70 \%$ of the time, with the lagging blastomere at the 2-cell stage tending to contribute cells predominantly to mural TE and the leading blastomere to ICM and polar TE. A possible explanation for the disparate outcomes of lineage tracing studies can be deduced from time-lapse experiments (Kurotaki et al. 2007; Motosugi et al. 2005) and computer modeling (Honda et al. 2008) that have implicated the ZP in influencing positional events during early embryogenesis. In particular, if the ZP, has a pronounced ellipsoid shape it can force embryos at the 2-cell stage to align along its longer diameter no matter where the plane of first cleavage occurred relative to the second polar body. If, thereafter, the embryo has only a limited ability to move, the initial location of 2-cell blastomeres and their progeny would be maintained until the blastocyst stage to provide a clonal population of cells concentrated at opposite poles of the zona. As blastocoel cavity formation is initiated towards one end of the embryo and generally appears to align with the long axis of the ZP, one population of cells, consisting of polar TE and ICM, would occupy the embryonic pole, a second, comprised largely of mural TE, the abembryonic pole. As predicted from this hypothesis, experimentally restricting the movement of embryos within the ZP provides blastocysts in which the clonal boundary is approximately orthogonal to the embryonic-abembryonic axis (Alarcon et al. 2008; Fujimori et al.2003; Kurotaki etal. 2007). On the other hand, even a limited amount of rotation would increase the contribution of the tagged blastomere to both poles, as the cavity would sub-divide the two clonal populations of cells. Hence, variation in the prop- erties of the ZP among mouse strains and according to how the embryo was derived and cultured provides a potential explanation for some of the contrasting results in lineage tracing experiments (Alarcon et al., 2008). The data presented in Table 5, which show that removal of the ZP increases the proportion of blastocysts with a randomized distribution of Dil-tagged cells, are consistent with this hypothesis. Thus, we suggest that the embryos derived from superovulated CF1 dams are less able to rotate within the confines of the ZP than embryos derived by normal ovulation. Whether these presumed mechanical constraints are the result of a more exaggerated ellipsoid shape or some other feature of the $\mathrm{ZP}$ is presently unclear.

As observed by some others (Piotrowska-Nitsche et al. 2005), a biased contribution to either the abembryonic and embryonic poles of the blastocyst occurred more commonly when the embryo passed through a 4-cell tetrahedral stage than through a conformation in which all four blastomeres were in approximately the same plane. Our work confirmed this result, and, importantly, demonstrated that an embryonic/abembryonic contribution was observed much more frequently in the tetrahedral embryos derived following superovulation than in CF-1 control embryos. Suzuki et al. (Suzuki et al. 1995) also showed that zona-free, mouse embryos more often than not adopted a planar rather than a tetrahedral conformation at the 4-cell stage, Again, the most likely explanation for our data is that embryos that pass through the tetrahedral conformation have a reduced potential to shift position, and that constraints on embryo rotation are more severe after superovulation than after normal ovulation. It is less clear why, in S embryos, the blastomere at the 2-cell stage that divides first tends to contribute predominantly to the embryonic pole of the blastocyst and the one that divides last predominantly to the abembryonic pole.

In conclusion, we suggest that at least some of the controversy regarding the establishment of the embryonic axis in mice stems from the source of the zygotes used in the lineage tracing experiments. In our studies, outcomes were very different according to whether natural breeding $(N)$ or superovulation $(S)$ was employed to generate embryos. We recognize that there are several reports where evidence for pre-patterning has been obtained from naturally bred mice (Bischoff et al., 2008; Gardner, 2001; Torres-Padilla et al. 2007), and so superovulation per se cannot explain all the contrasting results. On the other hand, it seems conceivable that either the shape, volume, or mechanical properties of the ZP of superovulated oocytes from CF1 dams is distinct from that in normally ovulated eggs even though such oocytes are capable of being fertilized and developing normally to blastocysts.

\section{Materials and Methods}

\section{Embryo collection and culture}

CF-1 females were induced to superovulate (S) by an intraperitoneal injection of pregnant mare serum gonadotropin (5 IU, Calbiochem, San Diego, CA) at $13.00 \mathrm{~h}, 46 \mathrm{~h}$ ahead of human chorionic gonadotropin injection (10 IU, Calbiochem) at $11.00 \mathrm{~h}$ on the day of breeding. CF-1 stud males were introduced to the female mice at $17.00 \mathrm{~h}$, and females selected for retrieval of 2-cell stage embryos between 10.00 and $11.00 \mathrm{~h}$ the day following observation of the copulatory plug, i.e. $\sim 36 \mathrm{~h}$ post coitus, pc. Alternatively, females were bred at estrus without superovulation (natural breeding). To collect 2-cell stage embryos, oviducts were flushed 
in CZB-Hepes buffer lacking glucose (mCZB-Hepes) between 10.00 and 11.00 on the second day after observing the copulatory plug ( 36 h pc). The culture of embryos was performed in KSOM-AA medium (Chemicon International, Philipsburg, $\mathrm{NJ}$ ) at $37^{\circ} \mathrm{C}$ under $5 \% \mathrm{CO}_{2}$ and $100 \%$ humidity (56 h pc for 4 -cell, $64 \mathrm{~h}$ for 8 -cell, and 84 and108 $\mathrm{h}$ for morula and blastocyst, respectively). In the case of NIH-Swiss mice, embryos at 2-cell stage were collected only by natural breeding, as the animals do not respond to the same protocol for superovulation as used for CF-1. Embryo collection and culture were performed identically to those used for the CF-1 strain.

\section{CM-Dil labeling of 2-cell stage embryos}

Micromanipulation of embryos was performed under an inverted microscope (Nikon, DIAPHOT-300) equipped with a standard micromanipulation system (Leitz, Model M). Two-cell stage embryos recovered at $36 \mathrm{~h}$ pc were transferred to microdrops of mCZB-Hepes covered with mineral oil on the stage of the inverted microscope. The embryo was secured by using a holding pipette, and a small drop of a membranesoluble, fluorescent dye, CM-Dil (Invitrogen, Eugene, OR) (1 mM in olive oil) was deposited on the surface of one of the two blastomeres. To accomplish this, the injection needle was backfilled with CM-Dil. The tip of the injection needle was then pushed through the ZP and pressed gently against the plasma membrane of the selected blastomere without penetration before releasing the oil droplet. CM-Dil has the advantage of providing a fluorescent signal even after the specimen has been chemically fixed and so can be viewed in association with immunofluorescent detection of $\mathrm{Cdx} 2$.

\section{Removal of ZP after labeling a blastomere of 2-cell embryos with CM- Dil}

After depositing a drop of CM-Dil on one of the 2-cell blastomeres (as described above), embryos were cultured for about $1 \mathrm{~h}$ in KSOM-aa to allow recovery from any stress and/or damage caused by micromanipulation. They were then exposed to acid Tyrode's solution (Sigma) until the ZP began to disintegrate and immediately washed with mCZB-Hepes to remove remnants of the structure. To avoid their sticking together, embryos were cultured individually in drops $(2 \mu \mathrm{l})$ of KSOM-aa until they reached the blastocyst stage $(108 \mathrm{~h} \mathrm{pc})$. Control embryos with ZP intact were cultured in parallel under the same conditions.

\section{Immunocytochemistry}

Embryos were fixed with 4\% paraformaldehyde in PBS containing 0.1 $\%$ polyvinyl alcohol (PVA) for $20 \mathrm{~min}$ at room temperature and stored in $1 \%$ bovine serum albumin in PBS (BSA-PBS) at $4{ }^{\circ} \mathrm{C}$ until processed further. After removal of the ZP with acid Tyrode's solution (Sigma, St. Louis, MO) under visual monitoring, embryos were treated with $0.1 \%$ Triton X-100 and $5 \%$ goat serum in PBS for 10 min at room temperature. To detect Oct 4 and Cdx2, the specimens were placed in a 1/1000 dilution of a rabbit polyclonal antibody raised against $\mathrm{N}$ - terminal region (amino acids 1 to 138) of recombinant Oct4 (Ezashi et al. 2005) and 1/100 mouse monoclonal antibody to Cdx2 (Biogenex, San Ramon, CA) in BSA-PBS overnight at $4{ }^{\circ} \mathrm{C}$. After washing with BSA-PBS, the specimens were incubated with secondary antibodies, Alexa Fluor 568 goat anti rabbit IgG and Alexa Fluor 488 goat anti mouse IgG (InVitrogen), at a 1:400 dilution in BSA-PBS for $2 \mathrm{~h}$ at room temperature. To visualize nuclei, the embryos were counterstained with DAPI (InVitrogen) diluted 1:600 with BSA-PBS). Embryos that had been tagged with CM-Dil were only stained for Cdx2 and DAPI. After mounting the specimens on slides, antigen distribution, number of nuclei and cell progeny labeled with CM-Dil were examined by Zeiss LSM 510 two photon confocal system. To determine whether individual blastomeres that had been labeled with CM-Dil at the 2-cell stage of development had distinguishable fates, i.e. had label confined primarily to either their embryonic or abembryonic poles, or demonstrated a more random distribution of labeled cell progeny with no biased distribution to either pole, we employed the approach described by
Piotrowska et al. (Piotrowska et al. 2001). Collected images were analyzed by Zeiss LSM Data Server, AimImageExaminer.

\section{Data analysis}

Cells were classified as either Oct4+/Cdx2+, Oct4+/Cdx2- or negative for both antigens. The latter were invariably cells in mitosis and were not included further in the analysis, as they could not be classified. The fraction of Oct4+/Cdx2- cells in an embryo was calculated as the number of Oct4+/Cdx2- cells divided by the sum of the Oct4+/Cdx2- and Oct4+/ $\mathrm{Cdx2}+$ cells. Differences in mean values between groups of embryos in a minimum of four different replicate experiments in total cell number, number of Oct4+/Cdx2- and Oct4+/Cdx2+ cells, and the fraction of Oct4+/ Cdx2- cells were assessed for significance by analysis of variance, with $\mathrm{P}<0.05$ considered significant (Table 1 ). In Tables 2-5, values were analyzed by using one-way analysis of variance (ANOVA), with $P<0.05$ considered significant.

\section{Acknowledgements}

We thank Steve Smith for assistance with embryo manipulation and staining and for helpful discussion. Dr. Andrei Alexenko provided mouse husbandry. The work was supported by NIH grant HD 21896.

\section{References}

ALARCON, V.B. and MARIKAWA, Y. (2003). Deviation of the blastocyst axis from the first cleavage plane does not affect the quality of mouse postimplantation development. Biol Reprod 69: 1208-1212.

ALARCON, V.B. and MARIKAWA, Y. (2005). Unbiased contribution of the first two blastomeres to mouse blastocyst development. Mol Reprod Dev 72: 354-361.

ALARCON, V.B. and MARIKAWA, Y. (2008). Spatial alignment of the mouse blastocyst axis across the first cleavage plane is caused by mechanical constraint rather than developmental bias among blastomeres. MolReprod Dev 75: 1143-1153.

BISCHOFF, M., PARFITT, D.E. and ZERNICKA-GOETZ, M. (2008). Formation of the embryonic-abembryonic axis of the mouse blastocyst: relationships between orientation of early cleavage divisions and pattern of symmetric/asymmetric divisions. Development 135: 953-962.

CHROSCICKA, A., KOMOROWSKI, S. and MALESZEWSKI, M. (2004). Both blastomeres of the mouse 2-cell embryo contribute to the embryonic portion of the blastocyst. Mol Reprod Dev68: 308-312.

DIETRICH, J.E. and HIIRAGI, T. (2007). Stochastic patterning in the mouse preimplantation embryo. Development 134: 4219-4231.

EZASHI, T., DAS, P. and ROBERTS, R.M. (2005). Low $\mathrm{O} 2$ tensions and the prevention of differentiation of hES cells. Proc Nat/ Acad Sci U S A 102: 47834788.

FUJIMORI, T., KUROTAKI, Y., MIYAZAKI, J. and NABESHIMA, Y. (2003). Analysis of cell lineage in two- and four-cell mouse embryos. Development 130: 51135122.

GARDNER, R.L. (2001). Specification of embryonic axes begins before cleavage in normal mouse development. Development 128: 839-847.

HIIRAGI, T. and SOLTER, D. (2004). First cleavage plane of the mouse egg is not predetermined but defined by the topology of the two apposing pronuclei. Nature 430: 360-364.

HONDA, H., MOTOSUGI, N., NAGAI, T., TANEMURA, M. and HIIRAGI, T. (2008). Computer simulation of emerging asymmetry in the mouse blastocyst. Development 135: 1407-1414.

JEDRUSIK, A., PARFITT, D.E., GUO, G., SKAMAGKI, M., GRABAREK, J.B., JOHNSON, M.H., ROBSON, P. and ZERNICKA-GOETZ, M. (2008). Role of $\mathrm{Cdx} 2$ and cell polarity in cell allocation and specification of trophectoderm and inner cell mass in the mouse embryo. Genes Dev 22: 2692-2706.

JOHNSON, M.H. and MCCONNELL, J.M. (2004). Lineage allocation and cell polarity during mouse embryogenesis. Semin Cell Dev Bio/15: 583-597.

KUROTAKI, Y., HATTA, K., NAKAO, K., NABESHIMA, Y. and FUJIMORI, T. (2007). Blastocyst axis is specified independently of early cell lineage but aligns with the ZP shape. Science 316: 719-723. 
MOTOSUGI, N., BAUER, T., POLANSKI, Z., SOLTER, D. and HIIRAGI, T. (2005). Polarity of the mouse embryo is established at blastocyst and is not prepatterned. Genes Dev 19: 1081-1092.

NIWA, H., TOYOOKA, Y., SHIMOSATO, D., STRUMPF, D., TAKAHASHI, K., YAGI, R. and ROSSANT, J. (2005). Interaction between Oct3/4 and Cdx2 determines trophectoderm differentiation. Cel/123: 917-929.

PIOTROWSKA-NITSCHE, K. and ZERNICKA-GOETZ, M. (2005). Spatial arrangement of individual 4-cell stage blastomeres and the order in which they are generated correlate with blastocyst pattern in the mouse embryo. Mech Dev 122: $487-500$.

PIOTROWSKA, K., WIANNY, F., PEDERSEN, R.A. and ZERNICKA-GOETZ, M. (2001). Blastomeres arising from the first cleavage division have distinguishable fates in normal mouse development. Development 128: 3739-3748.

RALSTON, A. and ROSSANT, J. (2008). Cdx2 acts downstream of cell polarization to cell-autonomously promote trophectoderm fate in the early mouse embryo. Dev Bio/313: 614-629.

STRUMPF, D., MAO, C.A., YAMANAKA, Y., RALSTON, A., CHAWENGSAKSOPHAK, K., BECK, F. and ROSSANT, J. (2005). Cdx2 is required for correct cell fate specification and differentiation of trophectoderm in the mouse blastocyst. Development 132: 2093-2102.

SUWINSKA, A., CZOLOWSKA, R., OZDZENSKI, W. and TARKOWSKI, A.K. (2008). Blastomeres of the mouse embryo lose totipotency after the fifth cleavage division: expression of $\mathrm{Cdx} 2$ and Oct4 and developmental potential of inner and outer blastomeres of 16- and 32-cell embryos. Dev Bio/322: 133-144

SUZUKI, H., TOGASHI, M., ADACHI, J. and TOYODA, Y. (1995). Developmental ability of zona-free mouse embryos is influenced by cell association at the 4-cell stage. Biol Reprod 53: 78-83.

TORRES-PADILLA, M.E., PARFITT, D.E., KOUZARIDES, T. and ZERNICKAGOETZ, M. (2007). Histone arginine methylation regulates pluripotency in the early mouse embryo. Nature 445: 214-218

WAKSMUNDZKA, M., WISNIEWSKA, A. and MALESZEWSKI, M. (2006). Allocation of Cells in Mouse Blastocyst Is Not Determined by the Order of Cleavage of the First Two Blastomeres. Biol Reprod75: 582-587.

ZERNICKA-GOETZ, M. (2006). The first cell-fate decisions in the mouse embryo: destiny is a matter of both chance and choice. Curr Opin GenetDev16:406-412.

\section{Further Related Reading, published previously in the Int. J. Dev. Biol.}

See Special Issue Pattern Formation edited by Michael K. Richardson and ChengMing Chuong at:

http://www.ijdb.ehu.es/web/contents.php?vol=53\&issue=5-6

Theoretical exploration of blastocyst morphogenesis

Rebecca J. Shipley, Michael B. Bonsall, David J. Allwright and Chris F. Graham Int. J. Dev. Biol. (2009) 53: 447-457

Early mammalian embryo: my love. An interview with Andrzej K. Tarkowski Marek Maleszewski and Andrzej K. Tarkowski

Int. J. Dev. Biol. (2008) 52: 163-169

Where do we stand now? - mouse early embryo patterning meeting in Freiburg, Germany (2005)

Takashi Hiiragi, Vernadeth B. Alarcon, Toshihiko Fujimori, Sophie Louvet-Vallée, Marek Maleszewski, Yusuke Marikawa, Bernard Maro and Davor Solter Int. J. Dev. Biol. (2006) 50: 581-588

Mouse chimaeras developed from electrofused blastocysts: new evidence for developmental plasticity of the inner cell mass

Andrzej K. Tarkowski, Kamila Jagiello, Renata Czolowska and Waclaw Ozdzenski Int. J. Dev. Biol. (2005) 49: 909-914

Development in vitro of Marsupials: a comparative review of species and a timetable of cleavage and early blastocyst stages of development in Monodelphis domestica L Selwood, E S Robinson, R A Pedersen and J L Vandeberg Int. J. Dev. Biol. (1997) 41: 397-410

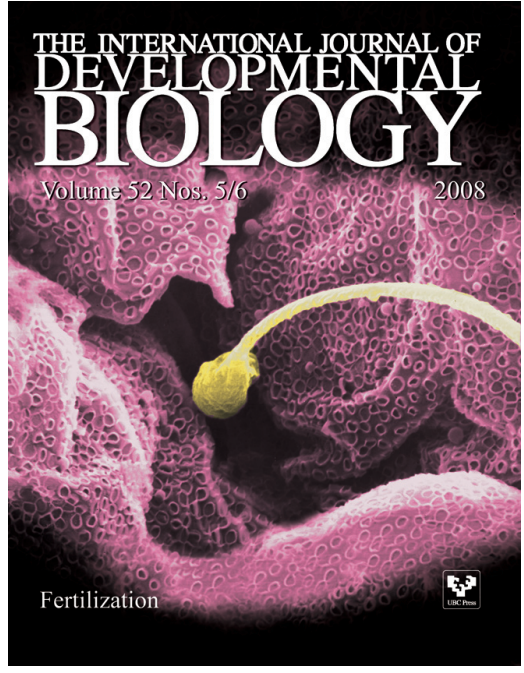

5 yr ISI Impact Factor $(2008)=3.271$

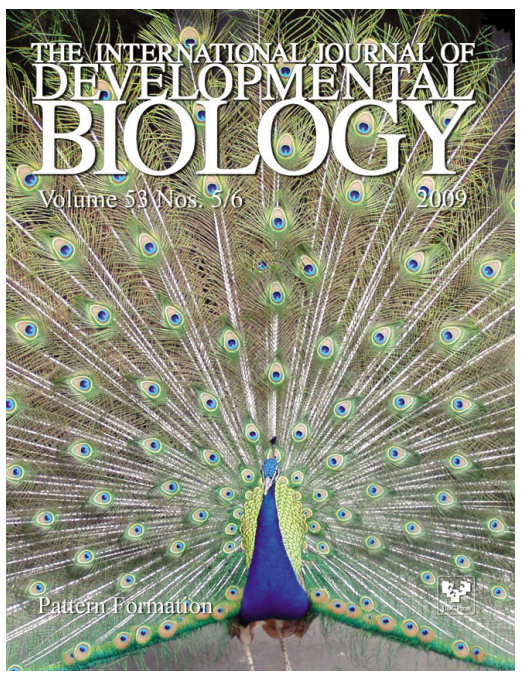

